\title{
What is Innovative Geography Teaching? A Perspective from Geography Teachers
}

\author{
Eyüp Artvinli \\ Correspondence: Eyüp Artvinli, Eskişehir Osmangazi University, Faculty of Education, Eskişehir, Turkey.
}

Received: April 20, 2017

doi:10.11114/jets.v5i6.2383

\author{
Accepted: April 23, 2017 \\ Online Published: April 23, 2017 \\ URL: https://doi.org/10.11114/jets.v5i6.2383
}

\begin{abstract}
The purpose of the study is to examine views of geography teachers on innovative geography teaching. The study group consists of 15 geography teachers (8 Females, 7 Males). The study is designed in keeping with phenomenological research. Semi-structured interview form is used as a data collection tool in the study. The collected data are analyzed through content analysis based on inductive analysis technique. Themes are derived from codes. The content analysis results reveal that the geography teachers are satisfied with their professions, the teachers who can keep up with technological and methodological developments in their field, are regarded as innovative teachers, innovative geography teachers are the ones who integrate new technologies into their lessons, the internet resources are the most significant application form in following the innovations, the participants consider making innovation in geography teaching as a part of their profession, and proficiency in the use of computers plays a crucial role in becoming innovative. The research findings have been discussed in relation to the literature and some recommendations have been given.
\end{abstract}

Keywords: Innovation, phenomenology, geography teacher, innovative teaching, content analysis

\section{Introduction}

\subsection{Introduce the Problem}

Today, there are many innovations and changes in the field of education in Turkey in order to catch up with the pace of developments in the field of science and technology as in the other countries of the world. In this context, it is noteworthy that the curriculum contents are organized for student-centered and questioning during the curriculum renovations.

In 2004, U.S.A. Business Secretary Elaine Chao argued that one of the three major decision-making areas of the 21 st century was spatial technology. In today's world, digital maps and the number of jobs that work with GIS are increasing day by day. For this reason, it is hoped that high school and college graduates should have spatial technology skills in line with the business world's expectations (Womac, 2015).

Four basic pillars of spatial technologies consist of geographical information systems, remote sensing, spherical coordinate system and digital spheres. Through the use of spatial technologies, students have the opportunity to improve themselves by becoming active, avoiding passive listeners in the classroom. The more we learn, spatial technologies' play a central and critical role in the learning of the 21st Century (Baker, Battersby, Bednarz, Bodzin, Kolvoord, Moore, Sinton and Uttal, 2015, Kocalar and Demirkaya, 2014).

Johansson (2003) emphasized that the main problem of using GIS applications in high school is the existence of GIS software and data. Many high schools in Finland have stated that they have modern computers on the internet for thematic map display and acquisition of GIS data. In their lessons, teachers who use internet habits have naturally claimed that they can also use basic internet-based GIS applications. But only a few teachers have been able to access the GIS over the Internet.

The greatest obstacle in front of geography education is that geography teachers move very slowly rather than accept GIS. However, this innovation offers many opportunities for geography education. The most important issues that teachers see as obstacles in front of GIS applications are unequal access to hardware and software, lack of pre-prepared needs (basic maps and databases) and lack of technical support (Bednarz and van der Schee, 2006).

In some schools, although a certain level of achievement is achieved at the school by the efforts of idealistic and 
innovative teachers, the administration that holds the initiative of change may be indifferent to it. However, some students may have a positive influence on school management in terms of success, development, and change (Carter, 2011).

Demir Başaran and Keles (2015) have reached the conclusion that teachers have an average level of innovation in their studies that aim to determine the innovation levels of teachers. They also examined the effects of gender, seniority year, institution and residence place variables on the teachers' innovation levels and determined that there is a significant difference according to the residence location variable.

Tüzün, Yılmaz-Soylu, Karakuş, İnal and Kızılkaya (2009) have suggested that the interest in geography in our 21st century is decreasing day by day as it needs to increase day by day. To increase the dissemination of innovative geography lessons in schools, researchers must ensure that their practical work is published in various journals to reach teachers. These activities will encourage the emergence of new relationships between the geography education community and scientists in literacy, mathematics and science education (Womac, 2015).

Alim and Altas (2005) suggested that the achievement of the objectives of geography education in high school geography course investigates teachers' views on contents and teaching process depends on the effective application of geography teaching methods and efficient use of necessary tools and materials in geography technology classes.

Bilgi (2008) argues that the use of technological materials for instructional purposes in geography lessons does not mean that active learning is practiced, and what is important is how technology is being used.

Akbulut (2004) emphasized the importance of learning geography in an environment that supports free and creative thinking and creating students in the student-centered learning environment by being active in the lessons in her research on the place of creative thinking in geography teaching.

Informal education in geography is not to be seen as tricky information. This knowledge is one of the most critical ways for teachers to acquire geographical knowledge and plays an important role in motivating them to teach geography. Geography teachers do not only travel for tourist purposes when they are on vacation but as a geographer and geography teacher, they aim to improve themselves. Teachers bring their stories and cultural backgrounds together in class. A researcher working on geography teachers should be aware of the importance of travel for a geography teacher. Besides, informal education (travel, reading, watching TV, etc.) and the experience of many geography teachers constitute the main sources of content knowledge (Mohan, 2009).

Akdemir and Yaşaroğlu (2013) claimed that the blackboard-chalk-teacher trilogy, which continues to exist today but is decreasing day by day, is now an important place in the geography teaching because some of the geographies covers the perception of some of the facts. Tüzün et al. (2009) have found that the use of smartboards in the lessons has significantly increased the success of geography lessons compared to non-smart board environments.

In traditional school systems, information is seen as unchangeable facts that are passed on to learners. While many teachers focus on knowledge and concepts, they avoid generalizations and relationships. Modern education, on the other hand, brings the meaning to the foreground by activating students. This epistemological change deepens and broadens the subject areas of the teachers and fosters the use of new pedagogical strategies. Teachers teaching GIS and GIS have to go beyond traditional ways of thinking and establish a remarkable balance when making strong connections to real practice (Stone Wiske, Sick, and Wirsig, 2001).

GIS requires having and using high-level thinking skills. Teachers and students have to work on new ways to improve these skills, such as inquiry-based methods and problem-based learning (Audet and Ludwig, 2000).

Kerski (2003) stated that geography teachers need to be trained effectively during teacher education when teaching with GIS, which will enable students to establish experiences about real-world problems, and if this cannot be done, teachers should be trained through in-service training.

Teachers are the key to change at school. The interaction of teachers with their students constitutes the basis of the school experience of the students. No curriculum has a magic power. The magical power in educational settings is teachers and students' (DeMitchell and Fossey, 1997: 52). Understanding what teachers' intentions are will provide an important clue for a successful school exchange. In this context, it can be said that geography-based tech enthusiast teachers are needed to support the students in acquiring knowledge, skills, and tools to make the world a more livable place.

The above-mentioned reasons have made it necessary for geography teachers to demonstrate how they describe innovative education and its components. For this purpose, it is important from the perspective of the geography teachers who are responsible for carrying out the geography courses in high schools to understand how to teach innovative geography suitable for today's conditions and to reach the aim of geography education. 


\subsection{Purpose of this Study}

The purpose of this research is to examine the geography teachers' views on the opportunities and obstacles in front of an innovative geography teacher. For this purpose, the following questions were asked:

1. What is the perception of geography teachers about "innovative geography teacher"?

2. What is the perception of the "innovative geography education" of geography teachers?

3. What are the practices that geography teachers have conducted in their courses regarding "innovative geography education"?

4. What are the opportunities and challenges that geography teachers encounter in "innovative geography training"?

\section{Method}

This research has been designed in accordance with the fact-scientific pattern of qualitative research methods. In case-awareness, but not in-depth knowledge, the fact-scientific statement that allows access to detailed explanations the identified phenomena needs to be elaborated on in detail the experiences of the different persons in order to be able to understand the case studied (Patton, 2002). Qualitative research aims to reveal the internal causes of unobserved human actions.

Qualitative researchers are interested in how people make sense of their own world and their experiences in their own world. The main aim of qualitative researchers is to understand facts, events, and events from the perspective of the participant (Merriam, 2009: 5-14). For this purpose, in case-scientific researches, it is preferred that the data sources be selected from the persons or groups who are experienced in the phenomenon focused on the research and who can explain this phenomenon (Yıldırım and Şimşek, 2005). The case studied in this study is the innovative geography teacher. The individuals selected in this direction are the secondary school geography teachers who have this experience directly.

\subsection{Working Group}

The study group of this research constitutes 15 geography teachers working in high schools in Eskişehir province center during Spring semester of the 2015-2016 academic year. For the interviews carried out within the scope of the research, 15 teachers were selected by the Purpose Unbiased Sampling method explained by Patton (2002) taking into account the number of geography teachers working at the secondary education institutions in Eskişehir city center. Eight of the geography teachers who participated in the research are female and 7 are male. 2 of participants have 0-5 year experience, two of them have 6-10 year experience, four of them have 11-15 year experience, two of them have 16-20 years' experience and five of them have more than 20 years' experience in teaching geography. Eight of the geography teachers graduated from geography department of the literature faculty or science-literate faculty, and 7 graduated from the geography teaching program in the faculty of education. Among the participants, 9 said they were "very satisfied" to geography teaching, while 6 said they were "satisfied" with geography teaching.

\subsection{Data Collection}

In the design of Phenomenology, the main data collection tool is the interview (Yıldırım and Şimşek, 2011, p. 74). The data of this study were collected through a semi-structured interview. Interviewing is the most commonly used data collection tool in qualitative research (Yıldırım and Şimşek, 2011, p.119). One of the strong features of the interview is that it provides information about the unobserved, and allows for alternative explanations on what is observed (Glesne, 2012, p.142). Semi-structured interviews are between structured and unstructured interviews (Karasar, 2006, p.168). In the semi-structured interview, the interviewer generally has a road map but tries to reveal the different dimensions of the subject by asking different questions in the general framework of the research according to the interest and knowledge of the interviewee. The interviewer has the opportunity to get enough information about the topic and to take the interview in a certain way. In addition, the interviewee will also be able to highlight points that are important to him/herself (Altunışık, Coşkun, Bayraktaroğlu and Yıldırım, 2005).

\subsection{Data Analysis}

The collected data during the research process were transformed into categories based on the questions asked to the participants. Primarily, content analysis-oriented research question and a scaffold with the questions that explore this research question were created. In this context, data were organized under these categories. In the second stage, by gathering data in a significant and rational way, quotations to be chosen were decided. Thus, the quotations chosen from the participants to be clear, understandable and consistent, relevant to experiences, credible, important and related directly to the research were taken into consideration. In the third stage, the organized data were identified and directly quoted at the findings part of the research. While giving place to quotations, numbers were given to each participant and coding from K1 to K15 was used. In the fourth stage, the predefined findings were interpreted. 


\subsubsection{Internal and External Validity}

In order to make this research, the research permission from the Turkish Republic Ministry of National Education was obtained. With the receipt of permission, the researcher went to the high schools randomly, and performed the interview in empty classes, teacher's room and on a bench in school's garden with geography teachers. During the interview, the researcher did not interfere with the participants' gestures and did not manipulate them. Throughout the research, all the expressions from the face to face interviews, were written down by the researcher instantly and reached to detailed and in-depth data. In every interview, expressions to be written were ensured to be approved by the interviewers in a stage which is determined to be appropriate to the process flow. The interviewing process has lasted approximately 3 weeks. The categories obtained from the data were also made accessible and approved by another domain expert. Thus, the internal validity of the research was tried to be ensured. The data obtained from the research findings that provide internal validity and are one of the most important variables, are appropriate to the research and significant. The data obtained in accordance with the sub-problems to be categorized by being described, makes the research findings consistent and significant. It was ensured that the research findings to be consistent with the conceptual framework. Conclusion and suggestions part to be consistent with the research data were taken into consideration.

External Validity: The working group of the research, interviewing places and process features were defined in detail to enable comparison by different research methods. The information of the working group created in accordance with the conceptual framework of the research, the data obtained and the findings reached are limited to the nature of this research, takes part in the conclusion and suggestions part.

\subsubsection{Internal and External Reliability}

Internal Reliability: In order to obtain the variables showing that the research results are independent the research, the researcher's comment has been given after being revealed directly and descriptively. Data analysis has been performed in accordance with the conceptual framework.

External Reliability: The research to be performed in the different high schools in Eskişehir, and participants to be appropriate to the research conditions are regarded to be one of the variables providing external reliability. Applications were performed in 10 different schools in Eskişehir in 3 weeks.

The role of the researcher in the research process is clarified under the sub-heading of internal validity. Data sources were identified. The obtained data medium was explained. Data collection tool and data analysis processes were described in detail.

\section{Findings}

Findings and comments are stated regarding sub research questions. The categories obtained as a result of the content analysis, were expressed with direct quotations by taking into consideration of the sub-problems. The research data was obtained considering the seniorities of the geography teachers and faculties they graduated. Categories obtained from the content analysis are given below.

While 8 geography teachers of the participant teachers indicated that they had to take education again so as to adapt to the innovations in the geography field, 7 of them stated that they do not need a new education. Some of the answers given by geography teachers are:

R2: "Yes, because I do not know a foreign language, I do not have a full knowledge of the technological innovations."

R3: "No, because I always adapt myself to innovations."

R4: "Yes, because I use smart board, but I use the tablets inadequately."

R5: "No, because I always renew myself by learning new information, doing researches and keeping myself up-to-date and making a point of a life-long learning, every time and everywhere."

R6: "Yes, because it is easier to draw and show the map, figure, graphic, photograph etc. to students on a computer."

R7: "Yes, because innovations progress rapidly especially in the field geography, so it is necessary from time to time."

R8: "Yes, because the development of technology requires us to renew ourselves."

R9: "No, because I always renew myself and keep myself up to the innovations."

R10: "No, because I have the knowledge of my profession."

R13: "Yes, because technology, smart board, Geographic Information Systems (GIS) become widespread."

R14: "Yes, because geography science changes and develops with the technology and science. At least the latest developments can be learned professionally with in-service training. Even if I made use of the opportunities in order to 
complete my education in that period's conditions, I do not think that it is enough in today's conditions of our country."

\subsection{What is the Perception of Geography Teachers of an 'Innovative Geography Teacher'?}

In this research, it is aimed at determining the perception of geography teachers of an innovative geography teacher, and their opinions concerning the education of geography, in order to learn how they define the innovative geography teacher, some questions asked such as; "How do you define an innovative geography teacher?", "How do you explain the characteristics of an innovative geography teacher?"(Can you explain it on an example), Is there any innovative geography teacher in your neighborhood? Can you please explain?" and "Can you tell your experiences related to being an innovative geography teacher? How did this experience affect you? How it made you think and feel?". The first three questions were analyzed together since they aimed at finding out what geography teachers ascribe meaning to an innovative geography teacher. The three answers given by geography teachers are below.

\section{A. How you define an innovative geography teacher?}

Answer 1: The person who follows the developments in his or her field and transfers it to his or her students (R2, R3, R4, R5, R6, R7, R10, R15).

R3: The person who is innovative and follows the developments and uses the new technological devices actively in his or her lessons.

R4: The person who follows and keeps up with the developments, learns through traveling and seeing, follows documentaries and makes students search for these documentaries, follows the periodicals.

R7: He or she has to be up to date and is aware of his or her deficiencies.

R10: The person who is aware of the changing and developing geographical events in the world and in Turkey and who transfers them to their students.

Answer 2: It is the person who follows technological developments and makes use of these technologies in his or her lessons (R3, R9, R11, R13, R14, R15).

Answer 3: The person who continuously renews himself of herself and adapts to change (R3, R5, R8, R13, R14).

R8: To be able to adapt to changes and developments over time. Improving himself or herself in that field.

R14: The teacher who follows the technological and scientific developments, and takes part in those activities within the bounds of possibilities. He or she has to renew himself or herself with various training. Besides, since geography is an environment lesson, he or she has to take part in environmental organizations and nature protection projects, and has to be a pioneer in this sense. He or she should not be traditional, and should love technology and science and look critically.

R15: The teacher who follows the developments about the field closely and uses technological developments in his or her lessons.

Answer 4: The person who analyzes the link between human-nature (R9, R12).

R12: Innovative geography teacher is who can teach the students that nature and human are a whole. Because geography is what we see in nature.

Answer 5: The person who teaches to use the information not to transfer it (R13).

R13: A teacher who is not dependent on his or her past notes and text books and uses all of the sources, materials and technology to transfer the targeted earnings on his or her program. Moreover, this is not the person who is only transmitting the information in the lesson, he or she is the one who teaches the students to reach and use the information.

Answer 6: The person who participates in the environmental organizations and nature protection projects (R13).

B. How would you describe the properties of an innovative geography teacher? (Could you give an example?) Do you know any innovative geography teachers? Could you please tell a little bit about it?

Answer 1: Able to use technology for the class and to keep an eye out for technological advances (R2, R4, R6, R7, R9, R10, R15).

R10: Is the one who learns and teaches geographical events by integrating technology.

R15: Uses technology during class. 7-8 years ago, for the first time, a friend of mine who worked at a private institution showed me a presentation that explained how it was possible to easily teach geography on the smart board installed in their classrooms. Afterward, when similar technological hardware was installed in the institutions we worked at, I started using this system at the school by doing some back-and-forth. There are several fellow innovative geography 
teachers at the schools with a good student and education profile.

Answer2: Researches, questions, always improve, is open to new knowledge and criticism (R5, R7, R14, R15).

R7: Open to criticism and able to keep up with technology.

Answer 3: Understands students and able to communicate with them in order to make geography appealing (R1, R4).

Answer 4: Able to explain geographical terms and environmental consciousness using visual and textual materials (R11, $\mathrm{R} 12)$.

Answer 5: Keeps updated about the innovations in his field, participates in training in his field (R13, R15).

R13: As an example, I want to talk about an experienced teacher friend of mine who currently teaches in Adana. First of all, he tries to participate in any seminar or training in his field. Gives interesting performance assignments to his students. For instance, he asks each of his students to interview one geography teacher about that teacher's city. Also, he enriches his classes with clips and videos that he shot himself. When appropriate, he presents animations and documentaries.

Answer 6: Teaches his students not only geography but life itself (R3).

Answer 7: Able to connect course subjects to current issues (R8).

Answer 8: Makes use of different materials during class (R4, R5, R6, R8, R9, R11).

R4: It is the teacher who makes geography appealing, introduces materials he has or finds to the classroom, lays out and presents documentaries, and takes the class on field trips. I can give as an example the field trip we took to the Bosporus in Istanbul.

R5: It is he who researches, questions, improves himself, is open to new knowledge, keeps on learning new things throughout life, and expresses curiosity. During class, I prefer to learn and teach by doing and applying over merely informing and memorizing. I tried to show my students how natural events occur by having them construct models. During a class on volcanism, we filled up a balloon with a thick, red liquid and put it into the mountain model we had constructed in order to make the students comprehend the subject better. When we applied pressure to the balloon, we are able to demonstrate how magma erupts from the ground. On the subject of the layers of the Earth, we made use of a boiled egg to explain the layers.

R11: Able to teach geographical concepts by visualizing them. For instance, we made a three-dimensional map with the students on the subject of isohyets.

C. Could you tell us about an experience of yours on being an innovative teacher? How did this experience affect you? What did you think of it and how did it make you feel?

R1: Keeping informed about the students' fields of interest (sports, arts, etc.).

R2: An inspector praised me for using computer technology for the class. I was pleased and this encouraged me to do more.

R3: When I was working at Denizli Çal High School, we opened for the first time a geography class (1998). It made the headlines all over the district and really motivated the students.

R4: I once saw the files containing performance assignments a geography teacher gave to the students. It was great. I thought about doing the same thing myself.

R5: When I used to work in the private sector, during a discussion with one of my students I felt inadequate due to my knowledge lacking and some of my knowledge being obsolete. After this incident, I made a promise to myself to improve myself and become a real geographer by always researching, always trying to obtain the maximum amount of knowledge on the subjects I teach, and replacing whatever obsolete knowledge I possess.

R6: I deliver visual presentations to my students. I take them to field trips.

K7: I transferred all my sources to the digital medium and enjoyed its convenience.

R8: My initial experience with using the smart board proved difficult. Thanks to my students' assistance, I've gotten adequate at it over time.

R9: Taking the kids to geographical trips, teaching classes visually, with student participation and with the use of tablets. This enables the students to comprehend the subject quicker.

R10: When I showed my students the footage I took of the newly formed volcanic island in the Pacific Ocean, I saw that they understood volcanism better. 
R11: I once drew a digital map using GIS, and my students were very impressed.

K13: After teaching for a while at a school where I had recently started working, my students asked me, "Are we not going to take notes? What kind of notebook do we need to buy?"

R14: I've been a teacher for two years. While this is not a lot of experience, we prepared a geographical magazine with the students of the school I worked at last year. This allowed me to get to know the region better and my students gained an environmental perspective.

R15: In 2007, I came across a nice presentation on pressure and winds. After teaching the subject using traditional methods, I repeated it using the presentation. My students loved this and reinforced their understanding.

\subsection{What is the Geography Teachers' Understanding of "Innovative Geography"?}

In order to learn how the geography teachers who participated in the research perceive innovative geography teaching, we asked them, "Who or what inspired you the most about becoming innovative (teacher, administrator, conference, TV program, etc.)? How did this inspire you?," "What do you think can be done to become an innovative geography teacher? Can you tell us about one of your experiences as an example? (Collaboration with various persons, institutions, and organizations, etc.)," "Do you see innovating geography teaching as part of your profession?," "What kinds of benefits do you think innovative teaching offers you or your students?," "Which additional expertise does an innovative geography teacher require (computer, foreign language, GIS, etc.)?," and "How does it contribute innovation to use technology for teaching (projection, tablet, interactive board, short film, slide show, documentaries, animation, etc.). Could you share your thoughts on this?" Because these six questions asked during the interview aims to reveal what innovative geography teaching means to the geography teachers, they were analyzed together. Below are the answers of the geography teachers to these six questions.

A. Who or what inspired you the most about becoming innovative (teacher, administrator, conference, TV program, etc.)? How did this inspire you?

Answer 1: The motivation to lifelong learning and being more helpful to my students in the current context (R1, R2, R3, R10).

R1: I tried to be more helpful to my students and feel closer to them. I was not inspired by any of it.

R3: My love for geography teaching was the deciding factor. I never start the class with inadequate knowledge and I like catching my students' attentions.

Answer 2: My professors during my university education (R5, R6, R12).

R12: On being innovative, the topical approach of my university professors ..., ..., and ... to the course subjects inspired me the most.

Answer 3: TV programs, the internet, documentaries, and popular geographical magazines (R4, R8, R14, R15).

R4: Documentaries on the TV; I am subscribed to the Atlas and Geo magazines. I love reading them regularly. I've been to about 60 cities in Turkey. I also want to see the places I haven't been to yet.

R14: Unfortunately, I don't see all that many innovative things around me. However, some of the TV program and documentary makers in foreign countries are especially creating interesting programs. I was very impressed by NASA's broadcast from outer space.

Answer 4: TÜBITTAK secondary education project competitions (R9, R11).

R9: Conferences. Occasionally participating in TÜBİTAK competitions and the innovative demeanor of our students required us to be innovative as well.

R11: We participated in TÜBİTAK competitions. This inspired me.

Answer 5: Administrators (R8, R9).

Answer 6: Conferences and seminars (R2, R9, R13).

Answer 7: My students (R1, R7, R9).

B. What do you think can be done to become an innovative geography teacher? Can you tell us about one of your experiences as an example? (Collaboration with various persons, institutions, and organizations, etc.)

Answer 1: Exploring-observing (R4, R5, R9, R10).

R5: At the Lice Anatolian High School, the first school I was appointed to, I saw that my students were unable to sufficiently comprehend the subject of landforms and decided to take them for a field trip. After getting the permission of the school administration and the District Directorate of National Education, I took them to the open fields. Because 
they witnessed first-hand the subjects I thought them, their learning was more permanent. I also showed other landforms not present in the vicinity in an attempt to make it stick in their minds.

Answer 2: Effective use of teaching technologies (R3, R6).

Answer 3: Devotion of self to the profession (R1).

Answer 4: Participating in conferences and seminars (R2, R7, R9, R15).

Answer 5: Participating in social projects (R8, R12, R13, R14, R15).

K8: For example, relevant to my field, I want to carry out a study with my students about recycling when I find the opportunity for it. And also give them an environmental perspective. To collaborate with certain institutions.

R12: It is especially necessary to replenish the students' green consciousness by collaborating with institutions such as TEMA. Building a memorial forest might be sufficient for this.

Answer 6: Getting a Master's Degree (R11, R13).

R11: I got a Master's Degree. It's been really beneficial for me.

C. Do you consider making innovation in teaching geography as a part of your job?

Answer 1: Yes, it is part of my job to innovate (R1, R2, R3, R4, R5, R6, R7, R8, R9, R10, R11, R12, R13, R14, R15).

R5: Since geography is a constantly evolving science field, it is not possible for our geography teachers to be stable without innovating. For this reason, we have to grow ourselves as one who keeps up with the constant improvement.

R12: I see myself as a part of my work. Of course, useful information can also be vaccinated in classical teaching. If innovations and classical teaching are blended, a more beautiful and instructive system can emerge.

R14: Innovation is not a part of my work, but it must be essence. I'm already at the beginning of my career. If I do not disappear in the system, I always want to use all the facilities and create new possibilities.

D. What do you think the innovative teaching provides to you and the students?

Answer 1: Train the equipped individuals (R1, R7, R11, R14).

Answer 2: Academic achievement (R2, R3, R6).

Answer 3: Teacher's self-renewal (R3, R5, R8, R13, R15).

R5: Innovative teaching has given me the feeling that I have to constantly improve myself. I do not think I can benefit my students when I can not renew myself.

R8: By adapting myself to innovations, I feel better and sufficient, and I think that I have saved students from stagnation by overcoming them.

Answer 4: Making learning fun (R4).

Answer 5: Persistent learning (R5, R9, R10).

R5: I only saw the dry learning by learning how to grasp the essence and make reasoning skills easier and more permanent.

R9: Students learn more permanently, effectively. They tell our friends what we do.

E. What additional expertise does the innovative geography teacher need? (Computer, foreign language, GIS, etc.).

Answer 1: Computer and internet usage (R1, R2, R3, R4, R6, R7, R8, R9, R10, R12, R13, R14, R15).

Answer 2: Use of GIS program (R3, R4, R6, R7, R8, R9, R11, R13, R14, R15).

R13: GIS is important for new activities and applications.

Answer 3: Knowing a foreign language (R5, R2, R3, R4, R6, R7, R8, R10, R11, R12, R13, R14).

R5: Due to the fact that geography is very up-to-date, change is open, and it is related to the whole world, it needs specialties such as computer and foreign language. Thanks to this expertise, it is both very useful and very easy for us to follow the innovations about the geography all over the world, to improve ourselves, to learn new information, to follow new sources in foreign sources and internet.

F. How does the use of technology in education (projection, tablet, interactive board, short film, slide show, documentaries, animation etc.) contribute to being innovative? Would you share your thoughts on this?

Answer 1: Provides visual learning (R1, R2, R3, R5, R7, R9).

R1: Visual use is important in geography lessons. Supporting the theoretical knowledge after visualization increases 
persistence.

R5: Geography is not just a lecture on the ears. Visuality in geography is very important. After we talk about an event (press formation, condensation, etc.) that we have not shown about figures, events or facts, we will show how to create animations, to create awareness with short films, to show photographs that will attract students' attention and to show documentaries, Wake up the curiosity and discovering feelings, will cause the gaze of the geography lesson to be positive.

Answer 2: It provides permanent learning: (R1, R9, R10)

R9: There is a positive contribution. Because, he saves from reciting. It allows children to learn visually and provides permanent learning.

R10: Interactive boards, slides and animations, short film screenings in our classes allow us to make presentations more comfortable to the students and increase the level of understanding of the course.

Answer 3: Increasing attention and interest of the learners: (R4, R6, R8, R11, R12, R13, R14, R15)

R8: Absolutely very effective. It is important to use this technology in order to attract the attention of the learners. It makes the lesson more enjoyable.

R13: It is useful when the scale and the time required by the course are used and the timing is well set. For example, if the Tundra climate is followed by a 5-minute Tundra document, the interest and attention of the students will increase.

R14: Certainly, the effect of technology on individuals is stimulated. It is much more effective than an individual talk. We need to benefit from technology in both the classroom environment and at the mass meetings when talking about the individual. We can thus maximize the perceptions of buyers. So we can turn the lesson and presentation into effective.

R15: Lessons are more enjoyable. The attention of the students is higher.

\subsection{What Are the Practices That Geography Teachers Have Done in Their Courses Regarding 'Innovative Geography'} Education?

From what sources do you gain access to innovations in teaching geography in order to reveal the opinions of geography teachers about the practical applications of innovative geography education? Please explain. ',' How do you develop your innovative role in your school and in various educational settings? Can you tell by example? "And" How does innovative teaching affect the classes and the school atmosphere? Are you able to tell an example you live in? "These three questions asked in the interview were analyzed together because they aimed to determine the practices that geography teachers carried out with regard to innovative geography education. Geography teachers' statements about these three questions are given below.

\section{A. From what sources do you gain access to innovations in geography teaching? Please explain.}

Answer 1: Internet (R1, R2, R3, R5, R8, R9, 10, R11, R14, 15).

$\mathrm{R} 1$ : The images on the internet helped us in this regard.

R5: The source I use the most is internet.

Answer 1.1: Teacher Portals: (R4, R13)

R4: I follow teacher portals. It's very useful.

Answer 1.2.: Geographical Sites: (R6, R7, R13, R15)

R6: Internet, geographical sites.

R8: There are some sites related to geography. From EBA and my helpful resource books.

R13: Shares in a geography group where I am a member of my priority resource. I scan myself on the Internet. There are sites like "mebgeology" that I use as a source. Geography sites are very helpful in sharing this with my friends on this subject.

Answer 2: Symposiums and Seminars (R3, R11).

Answer 3: Scientific books and magazines: (R5, R9, R13).

R9: Articles and books prepared by university students.

Answer 4: TV programs with recording feature (R10).

Answer 5: Selfie videos (R10).

R10: Videos taken during geographic trips. 
Answer 6: MoNE, Board of Education (R15).

B. How do you develop your innovative role in your school and in various educational settings? Could you please explain by example?

Answer 1: Creating a geography room in the school (R3).

Answer 2: Discussing the daily events in class (R1, R4).

Answer 3: Participating in interdisciplinary community meetings in school (R5).

R5: We are establishing dialogues between our teachers and our colleagues at our school. Especially since I have many common positions with the biology disciples, I ask them questions and exchange ideas to develop them better. In the chat environment I am opening topics to increase interest in geography.

Answer 4: By taking advantage of high-level information and communication technologies in my courses (R2, R6, R7, R8, R9, R10, R14, R15).

R9: When teachers use technology in the room, with the success of the lessons growing, it turns out that my classroom students are innovative with their conversations elsewhere.

R13: For example, I told the students who prepared the performance duties on the computer this year, to load their assignments to the smart board (D driver). They had students up to a certain age. Paper, CD etc. We did not use. Each student gave 5 minutes of homework. Many teacher friends later used this path.

Answer 5: By producing TÜBITTAK projects (R11).

C. What is the impact of innovative teaching on lectures and school atmosphere? Could you tell me an example you live in?

Answer 1: Student-teacher cooperation (R1, R6, R7).

R7: Student-teacher cooperation increases. Particularly, our independence with our students is getting stronger and students become more open to acquire more knowledge and skills.

R1: I think some problems can be solved spontaneously because it will be a peaceful and happy environment.

Answer 2: Increasing students' curiosity, researching and questioning (R8, R14).

R8: Apart from the narrative method, the lesson is to save the students from ordinary situations and to process more active lessons. I gave more attention to the students to use the technology to give examples from the current issues. They can see the lesson more enjoyable, they can make a better relationship with the surroundings. Feelings of worry are rising.

R14: I like the loud classroom and school atmosphere. The fact that my students are constantly exploring, speaking and questioning makes me more innovative. The existence of science classes is a necessity for innovative education by geographical clubs and organizations where specialist visits can be made from time to time (including inspectors), scientific visits or even teacher-student co-operation. Legal arrangements should be made about this, teachers should be given various rights and possibilities, financial facilities should be provided to schools separately for each lesson. In other words, geography teacher should be a practicing, guiding, approaching teacher with a scientific point of view, not a written and 2 performance appraisal for the term.

Answer 3: Students will be willing to attend classes (R2, R4, R5, R9, R10, R12, R15).

R5: When I started first in the Technical and Industrial Vocational Schools, I was told that a class from the 10th grade sleeps in classes and is not interested in classes. It was given to me in this class. When I went to the school, I saw that the students were very active when I started to get to know the students first. When the lessons start to work, students do not get interested and when they see that the students start to sleep, they will take photographs, articles, newspapers and news. Going to things, taking them to the topics and starting to include them as much as I could, I saw that the students were attending classes instead of sleeping. Sometimes, even if they say something wrong, can you say that instead of saying it wrong, what you're saying straight away is, in fact, like this? What else could it be? I have tried to establish their truth as their distinction with questioning questions such as.

R9: Positive effect. During the exams, the geographical successes increase. Students begin to enjoy the lesson, attention is gathered. Permanent learning is provided. I noticed that they have not forgotten the parallel and meridians theme, which I used to describe using the model sphere smart board, but I quickly realized that they had forgotten what I used to say (without the smart board). Speaking of these events in the teacher's room encouraged all teachers to use tablets, smart boards, and other visuals.

R10: Innovative teacher's lessons are lively, fluent, participative and willing. 
R12: Particularly important changes are made in the attitude of the students in the course. Geography, perceived as a boring and bad lesson, is perceived as a visual feast of the world with innovations. When you pay attention to visually in geography, you can get a positive answer from the student.

R15: Lessons become more enjoyable, students become more attentive.

Answer 4: Innovative teachers play a leading role (K3, R11).

R3: Innovative teacher has a positive contribution to the lectures. Like their own, their students become innovative. It also exemplifies teachers in the school setting. It feels like a need for self-renewal now.

R11: In the school environment, innovative teachers always drag other groups. Other teachers appreciate these friends.

Answer 5: Examination stress eliminates the stress (R13).

R13: Everyone is very uneasy about exam analysis. However, some friends share the programs they prepare with the help of macros (Excel) in the computer environment. Other teachers began using these programs. The school management agreed with BİLSA and decided to do some of the exams with an optical reader and an exam analysis program. As a result, you can not see the results without trying a method. You can get help from experienced, experienced, and successful ones.

\subsection{What are the opportunities and obstacles that geography teachers encounter in 'innovative geography' training?}

What are the opportunities in front of you to become an innovative teacher in order to reveal the opinions of the geography teachers about the opportunities and obstacles they encountered during the innovative geography education? Could you give me an example of what you are living in? "," What are the obstacles to becoming an innovative teacher? Can you give us an example of what you are living in? "And" Is the school administration supporting you as an innovator? How? Tell us' questions were directed. These three questions asked in the interview were analyzed together because geography teachers aimed to identify opportunities and obstacles they encountered during innovative geography education. Geography teachers' expressions about these three questions are given below.

A. What are the opportunities in front of you as an innovative teacher? Could you give me an example of what you live in?

Answer 1: Easy access to information (R1, R4, R5, R6, R7, R8, R10).

R5: There are many opportunities ahead. In the past, it was very difficult to access information, and we were reaching out to the big encyclopedia. Today, for MoNE It is important that students have the opportunity to do lots of research (internet, magazine, book etc.).

R6: The use of smart boards and the Internet is widespread.

Answer 2: Development of instructional materials (R2).

Answer 3: To teach in a high school of success (R3).

Answer 4: To carry out project work (R9, R15).

R9: To be able to participate in scientific and academic in-service training activities. I once participated in the TUBITAK study and always devoted myself to being innovative.

Answer 5: Making an academic career (R11, R15).

Answer 6: Participating in in-service training seminars (R13, R15).

Answer 7: There are is no opportunity (R14).

R14: The only thing that can be done as a national education staff is to follow the developments related to geography and to be informed. Unfortunately, we do not have opportunities.

$B$. What are the obstacles to becoming an innovative teacher? Could you give me an example of what you live in?

Answer 1: There are no obstacles to be immersed (R1, R8, R11).

R1: After the teacher wants to overcome all obstacles.

R8: First, prejudice is a big obstacle. We will make believe and make students believe they can do it.

R11: The only obstacle for this is the person himself. If the person does not want happens.

Answer 2: School management (R2).

Answer 3: Inadequate in-service training seminars (R3, R15).

R15: The activities such as courses, projects, seminars are in the course of the year so that the teachers do not easily 
take such trainings because they accept this training even though the ministry opens in-service training as a branch.

Answer 4: Restrictions and prohibitions on sightseeing (R4, R14).

Answer 5: Traditional education system (R5, R9, R12, R13).

R5: The biggest problem we are facing is that our students are educated in a memorizing logic and unquestioned, unexplored. It is difficult and time-consuming to change the behavior of students who have used it. For example, students will come to school without examining the essays or memorizing homework assignments. If they are successful in the exam, we see that they forget the exam after 1-2 weeks from the exam. If the subject is the same, we cannot answer because we do not have the reasoning ability that we ask in a different way of memorizing our questions.

R9: Some teachers say, 'What do you need them for?

R13: As a formator, I made a three-hour briefing with the teacher friends in the province. Especially senior people in the profession are prejudiced about technology and other new teaching systems.

Answer 6: Financing problem (R6, R10, R14).

R10: The biggest obstacle in this regard is the lack of economic equality to ensure that all students in the classroom go on the same course in geography teaching based on sightseeing and observation.

Answer 7: University entrance exam (R7).

R7: There are no obstacles. However, it is difficult for the students to prepare for the test during the training.

C. Does the school administration support you as an innovator? How?

Answer 1: Yes, providing internet, smart boards and tablets: (R1, R4, R5, R7, R8, R9, R10, R11, R12, R15)

R8: We have all kinds of opportunities at our school. He definitely supports in an activity I plan to do.

R9: It's happening. If there is a problem with smart boards and tablets, they are immediately repaired and maintained. They are trying to help with internet connection.

Answer 2: Does not support: (R2, R3, R6, R14)

R3: Management does not contribute much to us. But they do not stop what we want to do.

R6: They can not help because of insufficient financial resources.

Answer 3: They support geographical trips: (R4)

Answer 4: Exhibition and projects: (R13)

R13: Yes, he does. They can transfer resources in exhibitions and projects. They take it when we have a proposal.

Answer 5: To make an academic career: (R13)

R13: Yes, he does. It supports every aspect, including post-graduate education.

\section{Conclusion, Discussion, and Recommendations}

When the findings of the research are examined in a holistic approach, it is seen that the geography teachers are open and willing to use current education technologies in their classes, but with some obstacles. This is an important result of the fact that these preferences of the teachers are consistent with the goals of developed countries and geography teaching programs in Turkey. Thus, it is envisaged that possible teacher education programs, geography teaching programs, graduate / non-thesis graduate education, in-service training programs and teaching practice processes which are considered to be developed can be structured by making use of the findings obtained from this study.

Despite the fact that nearly half of the survey participants say that they need to retrain to keep up with innovations in geography education, it has been understood that geography teachers need to retrain in their lessons in order to be able to function using current technologies when analyzing answers to the explanatory questions directed to them. Thus, it can be said that geography teachers have to take an education other than undergraduate education and that there is a close relationship between the use of current technologies in their lessons and the yield in their courses. Korevaar and van der Schee (2004) In a survey in which geographical teachers participating in an in-service training seminar in Holland evaluated GIS-related thoughts, it was found that $12 \%$ of the teachers used GIS in their geography courses, $81 \%$ of them used GIS more in geography teaching, 'In GIS should be mandatory in geography teaching and $87 \%$ in case of organizing, the result that they want to participate in in-service GIS training related to geography teaching has been reached.

It is understood that the innovative geography teacher is defined as teachers who can continuously analyze the society and the world in which they live, in the context of human-environment relation, follow the developments in geography 
education and use these methods and technologies effectively in their lessons. Boshuizen and Wopereis (2003) emphasize the rapidly changing role and structure of information and communication technologies in education and point out that the technology integration in today's educational applications is at a low level and that multilevel approaches to integration of knowledge and practice in educational settings are needed. Bednarz and van der Schee (2006) argued that the GIS software and materials used in the study period were not designed to meet the needs of the geography teachers, in addition to the technical skills, to improve student learning. Today, no need to teach GIS-oriented software such as Google Earth and so on. The programs are designed to be easily used in a student and teacher-friendly manner in the educational environment. Teachers who are willing to do this have the chance to implement these applications in their classrooms through the manuals of the videos and software they can watch on the internet.

Participants of the study were able to use technology in the course of an innovative geography teacher and follow technological developments, utilize different materials while studying, and investigate the questioner who keeps open to new information and criticism. They should have features.

It is understood that the participants of the research are based on the use of technology in their lessons, in the course of their innovative geography teaching experiences, in general, in their lessons, or on the use of methods such as trips and observation. Wiegand (2004) suggests that despite the educational campaign with GIS, which was launched in England about 10 years ago, very little progress has been made and that the use of GIS in schools is still limited. Because geography teachers have always been using their textbooks and narrative methods to teach their lessons. Teachers who are not open to innovation can resist using innovative technologies in their lessons.

It is expected that students will be beneficial to the students in the context of lifelong learning and in the contemporary context and that they will be able to benefit from the activities of university students during their university education on the Internet, watching TV programs and watching periodicals, participating conferences and seminars, TÜBITAK project competitions and innovative geography education using new teaching systems and technologies It is understood that there are factors that are effective on.

It is understood that the geography teachers who are seen as innovative by the geographical teachers participating in the research use more of the trip-observation method, participate in the social projects, attend the conferences and seminars, receive post-graduate education and use educational technologies effectively.

It is understood that all of the geography teachers who participated in the research regard innovation as an integral part of their lessons, active use of teaching methods and technologies. Technology-savvy teachers have innovative teaching methods and better innovative performance in their strategies, with the ability to find the information they are looking for from a large amount of information available on the internet where information from multiple sources is integrated. These teachers effectively use this knowledge to solve teaching problems and apply them to educational technology in teaching practice (Zhu et al., 2013).

Geography teachers say that if the innovations are used effectively in lessons, the students will be more equipped, the teacher will be able to renew himself, the permanent learning will take place and the lessons will become more fun.

It is understood that the participants of the research use computer technology skills and the level of foreign language use are important because the effect of a geography teacher on innovation is important. It is seen that the participants of the research used technology in education to inform the students that they will increase their attention and interest, provide visual learning and contribute to permanent learning.

It is understood that the participants of the research had access to the internet, scientific books and magazines, symposiums and seminars on innovations related to geography education. The innovative use of Chen (2009) teaching resources is directly proportional to the teacher's ability to transfer library, the internet, school and social resources to instructional sources with an innovative approach.

It is understood that the participants of the research demonstrate their role as innovative geography teacher by taking advantage of the highest level of information-communication technologies in their best courses. Teachers must attract the attention and attention of students using appropriate innovative approaches. The objectives of innovative education can be achieved through the employment of information and communication technologies necessary for the students to reach their potential (Ferrari, Cachia and Punie, 2009). Hannon (2008) suggests that a number of studies reveal the change in the concept of innovation in education through the use of educational technologies. It can be predicted that the students who are educated by the teachers with high technology ability who can use the desired information effective access and up-to-date technology will play an important role in the development of the societies. Thus, it can be said that the innovative geography teachers who demonstrate these skills have also been leading the social development.

Participants of the study found that innovative educational practices positively influenced the school and classroom 
atmosphere, especially when the students reported that their attendance and desire for classes increased. Kocalar and Demirkaya (2014) argued that geography teachers could exhibit a negative attitude towards geography because of the fact that geography teachers do not use the technological tools and tools effectively in their studies in high school geography study.

It is understood that the participants of the research are the most important opportunities for being innovative geography teachers as they have easy access to information, academic career opportunities and in-service seminar facilities in today's conditions. There are many publications suggesting that doing post-graduate education positively contributes to the professional development of teachers and responds to expectations (Turhan and Yaraş, 2013; Başer, Narlı and Günhan, 2005).

It is understood that the survey participants said that the biggest obstacle they faced in becoming an innovative geography teacher is the traditional education system, the financing problem, the regulation of the trips, and the limitations of in-service training opportunities. Lunde and Wilhite (1996) have found that innovative teachers have a passion for teaching and are aware of their role in the learning-teaching environment they are at risk, needing freedom, in their work on the improvement of innovative teacher and teaching.

It is understood that the researchers say that the school administration supports them by providing them with internet, smart boards and tablets in order to make the participants innovative.

The responsibility of high school geography teachers should not be to just tell their lessons in the textbook. Geography teachers should bravely adopt innovative educational understanding and engage them in innovative educational systems and technologies that will make their students active in their lessons. Thus, both teachers and students will gain mental competence and will be able to evaluate opportunities to gain current learning skills expected of $21^{\text {st }}$-century people. In order for these expectations to be realized, necessary infrastructure has been established in the secondary education geography curriculum updated in 2016.

\section{References}

Akbulut, G. (2004). Coğrafya Öğretimi ve Yaratıcı Düşünce. Cumhuriyet Üniversitesi Sosyal Bilimler Dergisi, 28(2), 215-223.

Akdemir, E., \& Yaşaroğlu, F. (2103). The investigation of the effects of using the smart board on the achievement of students in geography courses. International Journal of Human Sciences, 10, 76-97.

Alım, M. ve Altaş, N. T. (2005). Coğrafya Öğretmenlerinin Dokuzuncu Sınıf Coğrafya Dersinin İçeriği ve Öğretim Süreci Hakkındaki Görüşleri, Milli Eğitim Dergisi, 168, Retrieved from http://www.yayin.meb.gov.tr

Altunışık, R., Coşkun, R., Bayraktaroğlu, S., \& Yıldırım, E. (2005). Sosyal Bilimlerde Araştırma Yöntemleri. Sakarya: Sakarya Kitabevi.

Audet, R., \& Ludwig, G. (2000). GIS in schools (Redlands, CA, ESRI).

Baker, T. R., Battersby, S., Bednarz, S. W., Bodzin, A. M., Kolvoord, B., Moore, S., Sinton, D., \& Uttal, D. (2015). A research agenda for geospatial Technologies and learning. Journal of Geography, 114, 118-130. https://doi.org/10.1080/00221341.2014.950684

Başer, N., Narlı, S. ve Günhan, B. (2005). Öğretmenlerin Lisansüstü Eğitim Alanlarında Yaşanan Sorunlar ve Çözüm Önerileri, Dokuz Eylül Üniversitesi, Buca Ĕgitim Fakültesi Dergisi, 1, 129-135.

Bednarz, S. W., \& van der Schee, J. (2006). Europe and the United States: The implementation of geographic information systems in secondary education in two contexts. Technology, Pedagogy and Education, 15(2), 191-205. https://doi.org/10.1080/14759390600769573

Bilgi, M. G. (2008). Ortaöğretim kurumlarında coğrafya dersi kapsamındaki çevre konularının öğretiminde aktif öğretim yöntemlerinin rolü. Gazi Üniversitesi Eğitim Bilimleri Enstitüsü. (Yayınlanmamış Doktora Tezi), Ankara.

Boshuizen, H. P. A., \& Wopereis, I. G. J. H. (2003). Pedagogy of training in information and communications technology for teachers and beyond. Technology, Pedagogy and Education, 12(1), 149-160. https://doi.org/10.1080/14759390300200150

Carter, M. H. (2011). Independently Innovative: Teachers and Change in Successful Schools. University of New Hampshire (Unpublished Doctoral Dissertation), New Hampshire.

Chen, S. C. (2009). A study of the Relations between Innovative Teaching Capacity and Teaching Effectiveness of Teachers in Elementary and Junior High Schools in Penghu County. Retrieved from http://ndltd.ncl.edu.tw/cgi-bin/gs32/gsweb.cgi/login?o=dwebmge\&cache=1283038497890. 
Demir Başaran, S., \& Keleş, S. (2015). Who is Innovative? Examination of Teachers' Innovativeness Level. $H . U$. Journal of Education, 30(4), 106-118.

DeMitchell, T., \& Fossey, R. (1997). The limits of law-based school reform: Vain hopes and false promises. Lancaster, PA: Technomic Publishing Co., Inc.

Ferrari, A., Cachia, R., \& Punie, Y. (2009). Literature review on Innovation and Creativity in E\&T in the EU Member States. Retrieved from http://www.jrc.ec.europa.eu/

Glesne, C. (2012). Nitel Araştırmaya Giriş, (Çev. Editörleri: Ali Ersoy ve Pelin Yalçınoğlu). Ankara: Anı Yayıncılık.

Hannon, J. (2008). Breaking down online teaching: Innovation and resistance. Conference proceedings from ASCILITE 2008 Hello! Where are you in the landscape of educational technology? Melbourne, Australia, 389-399.

Johansson, T. (2003). GIS in teacher education-Facilitating GIS applications in secondary school geography. In K. Virrantaus \& T. Håvard (Eds.), The 9th Scandinavian Research Conference on Geographical Information Science (pp. 285-293). Finland: Helsinki University of Technology.

Karasar, N. (2006). Bilimsel Araştırma Yöntemi. Ankara: Nobel yayın Dağıtım.

Kerski, J. J. (2003) The Implementation and Effectiveness of Geographic Information Systems Technology and Methods in Secondary Education. Journal of Geography, 102(3), 128-137. https://doi.org/10.1080/00221340308978534

Kocalar, A. O. \& Demirkaya, H. (2014). Why is geography important to learn? Perception of high school students. Eastern Geographical Review, 32, 123-144.

Korevaar, W. \& van der Schee, J. (2004). Modern geography education using GIS has been put on the map. Geografie [Geography], 13(9), 44-46.

Lunde, J. P. \& Wilhite, M. S. (1996). Innovative teaching and teaching improvement. In L. Richlin (Ed.), To Improve the Academy, 15, 155-167.

Merriam, S. B. (2009). Qualitative research: a guide to desing and implementation. San Francisco: Jossey-Bass Publishers.

Mohan, A. M. (2009). Teacher efficacy in geography: A mixed methods of formal and informal teacher education. Texas State University-San Marcos (Unpublished Doctoral Dissertation), Texsas, U.S.A.

Patton, M. Q. (2002). Qualitative research \& evaluation methods (3rd ed.). Thousand Oaks, CA: Sage Publications.

Stone Wiske, M., Sick, M., \& Wirsig, S. (2001). New technologies to support teaching for understanding, International Journal of Educational Research, 35(5), 483-501. https://doi.org/10.1016/S0883-0355(02)00005-8

Turhan, M., \& Yaraş, Z. (2013). The contribution of graduate programs to Professional development of teachers, administrators and inspectors. Electronic Journal of Social Sciences, 12(43), 200-218.

Tüzün, H., Yılmaz-Soylu, M., Karakus, T., İnal, Y., \& Kızılkaya, G. (2009). The Effects of Computer Games on Primary School Students' Achievement and Motivation in Geography Learning, Computer \& Education, 52(1), 68-77. https://doi.org/10.1016/j.compedu.2008.06.008

Wiegand, P. (2004). Maps and supermaps, in: A. Kent, E. Rawling \& A. Robinson (Eds) Geographical education, expanding horizons in a shrinking world (Glasgow, ICA/IGU), 152-158.

Womac, P. (2015). The origin of effective elementary geography instruction: A multiple case study of exemplars. Graduate School of Clemson University, (Unpublished Doctoral Dissertation), U.S.A.

Yıldırım, A. \& Şimşek, H. (2005). Sosyal bilimlerde nitel araştırma yöntemleri. (5. Baskı). Ankara: Seçkin Yayıncılık.

Zhu, C., Wang, D., Cai, Y. \& Engels, N. (2013). What core competencies are related to teachers' innovative teaching? Asia-Pacific Journal of Teacher Education, 41(1), 9-27. https://doi.org/10.1080/1359866X.2012.753984

\section{Copyrights}

Copyright for this article is retained by the author(s), with first publication rights granted to the journal.

This is an open-access article distributed under the terms and conditions of the Creative Commons Attribution license which permits unrestricted use, distribution, and reproduction in any medium, provided the original work is properly cited. 